\title{
テキストマイニングによる敗血症患者の看護カルテ自由記載 中の語句と転帰に関する検討
}

\author{
小林 直也*1 中川 敦寛 $* 2$ 石垣 司*4 工藤 大介*3 \\ 新妻 邦泰*2 川口 奉洋*2 冨永 悌二*2 山内 正憲*1 \\ *1 東北大学大学院医学系研究科麻酔科学 - 周術期医学分野, $* 2$ 同 神経外科学分野, $* 3$ 同 救急医学分野 \\ （干 980-8575 宮城県仙台市青葉区星陵町 2-1） \\ ${ }^{* 4}$ 東北大学大学院経済学研究科 ( $=980-8576$ 宮城県仙台市青葉区川内 27-1)
}

Key words: (1) blood pressure, (2) sepsis, (3) text-mining

\section{はじめに}

敗血症患者における循環変動は予測が困難であり, 日常 業務において大きな問題となっている。特に夜間や休日な どの医療スタッフが少ない状況下では, 担当看護師による 観察が重要であり, その経験や能力によって治療開始の夕 イミングは大きく左右されている可能性がある。現在, バ イタルサインは電子カルテに自動収集されていることが多 いが, 循環変動の予測はできておらず, early warning systemの作成をはじめとする様々な取り組みがなされて いる1)。一方, カルテに自由記載されるテキストデータは, 統計学的処理が困難であるためデー夕解析には用いられて いない。

近年，テキストマイニングと呼ばれる手法により，これ らの定性デー夕解析を支援するソフトウェアが登場してお り, 様々な分野への応用が期待されている。その目的とし ては, 結果に影響する膨大な種類の因子の中から注目すべ き項目に焦点を当てたり, 従来注目されていない因子を発 見したりすることにあるが, 医療分野のテキストデータは 医療スタッフの豊富な経験や能力が反映される可能性があ り, 定量データよりもより早く異常を発見できる可能性が ある。

本研究では, 担当看護師をはじめとする医療スタッフの 経験や能力が反映されうるテキストデータが, 転帰予測に 使用できる因子であるかを検討するため, テキストそのも のの出現数と転帰との関係を比較した。

\section{対象と方法}

本研究は東北大学医学系研究科倫理委員会の承認 (承認
番号: 2014-1-807) を得て行われた後向き調査である。 2008 年 1 月から 2015 年 1 月の間に当院ICUに入院し, 部門 カルテシステムの病名欄に「敗血症」を含む成人を自動的 に抽出した。この患者群の中から, 入室時に感染症が疑わ れ，入室後 24 時間でのSOFA score $\mathrm{H}^{2)} 2$ 点以上の患者を対 象とした。72時間以内にICUを退室した症例は除外した。 対象症例を ICU入室後 90 日の転帰で生存群, 死亡群の 2 群 に分けて解析した。

まず, 看護カルテのテキストデータを「.txt」ファイルとして 取り出し, 医学辞書3)を語句として登録したCoreExplorer ${ }^{\circledR}$ (日立ソリューションズ東日本) を用いて形態素解析 (文 章を最小単位である形態素に分割して品詞を見分ける作 業) 4)をした。単語は名詞, 動詞, 形容詞のみを対象として, 出現頻度を自動解析した。次に, 入室から 72 時間後まで に1回でも使用された単語の症例数を算出したところ, 最 も多く使われていた単語が「BP」であった。そこで，血圧 を意味する語句〔血圧, BP, NIBP (noninvasive blood pressure), ABP (arterial blood pressure) の 4 語を対象と し, IABP (intra-aortic balloon pumping) などの血圧と関 係しない語は除外了と, 低下または上昇を意味する語句や

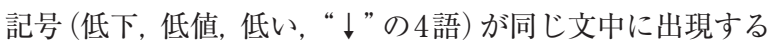
ものを目視で抽出し, それぞれ入室 $0 \sim 24,24 \sim 48,48 \sim$ 72 時間後に分けて転帰について解析した。

\section{結 果}

54 例 (90日生存群 32 例, 死亡群 22 例) を対象とした。 72 時間以内にICUを退室した症例はなかった。24時間ごと の延べ症例 (総数 162 例) において, 両群ともに「BP」とい う単語が最も多く出現していた〔生存群: 60/96人

\section{Text-mining-analysis about outcome in sepsis patients}

Naoya Kobayashi*1, Atsuhiro Nakagawa*2, Tsukasa Ishigaki*4, Daisuke Kudo*3, Kuniyasu Niitsuma*2,

Tomohiro Kawaguchi*2, Teiji Tominaga*2, Masanori Yamauchi*1

${ }^{* 1}$ Department of Anesthesiology and Perioperative Medicine, *2 Department of Neurosurgery, ${ }^{* 3}$ Division of Emergency and Critical Care Medicine, Tohoku University Graduate School of Medicine (2-1 Seiryomachi, Aoba-ku, Sendai, Miyagi 980-8575, Japan)

${ }^{* 4}$ Graduate School of Economics and Management, Tohoku University (27-1 Kawauchi, Aoba-ku, Sendai, Miyagi 980-8576, Japan) 
日集中医誌 J Jpn Soc Intensive Care Med Vol. 24 No. 6

Table 1 Exact value of MAP and frequency of appearance of words about increase or decrease blood pressure

\begin{tabular}{|c|c|c|c|c|}
\hline $\begin{array}{l}\text { Duration from ICU } \\
\text { admission }\end{array}$ & Blood pressure & $\begin{array}{l}\text { Survivors } \\
(\mathrm{N}=32)\end{array}$ & $\begin{array}{l}\text { Non-survivors } \\
(\mathrm{N}=22)\end{array}$ & $P$ value \\
\hline \multirow[t]{3}{*}{$0 \sim 24 \mathrm{hr}$} & Exact value of MAP & $79.9 \pm 11.6$ & $79.2 \pm 13.7$ & 0.848 \\
\hline & Decrease & $23(71.9 \%)$ & $9(40.9 \%)$ & $0.028^{*}$ \\
\hline & Increase & $19(59.4 \%)$ & $8(36.4 \%)$ & 0.166 \\
\hline \multirow[t]{3}{*}{$24 \sim 48 \mathrm{hr}$} & Exact value of MAP & $87.7 \pm 9.6$ & $80.2 \pm 16.7$ & 0.069 \\
\hline & Decrease & $6(18.8 \%)$ & $9(40.9 \%)$ & 0.121 \\
\hline & Increase & $12(37.5 \%)$ & $6(27.3 \%)$ & 0.560 \\
\hline \multirow[t]{3}{*}{$48 \sim 72 \mathrm{hr}$} & Exact value of MAP & $89.4 \pm 11.2$ & $76.2 \pm 10.9$ & $<0.001 * *$ \\
\hline & Decrease & $2(6.3 \%)$ & $10(45.5 \%)$ & $0.002 * *$ \\
\hline & Increase & $6(18.8 \%)$ & $6(27.3 \%)$ & 0.517 \\
\hline
\end{tabular}

MAP were averaged using all data during any period. "Decrease blood pressure" means sentence contain the words about blood pressure (ex: arterial pressure, BP, etc.), and the phrase or sign to mean a drop (ex: low, decrease, " $\downarrow$ ” etc.). We excluded the sentence that a drop was denied in the same sentence. We handled "increase" like "decrease". For statistical analysis, Fisher's exact probability test were used. ${ }^{*}: P<0.05,{ }^{*}: P<0.01$.

$(62.5 \%)$, 死亡群 : $34 / 66$ 人 $(51.5 \%)$ ]。

「血圧低下」,「血圧上昇」を意味する語句を確認し，出現 頻度を分析した (Table 1)。「血圧低下」を意味する語句が 出現した人数は, 入室後 24 時間では生存群において有意に 多く,24〜48時間においては, 群間差を認めなかったが 48〜 72時間では死亡群において有意に多く出現した。「血 圧上昇」は全ての時間帯において群間差を認めなかった。

実際の血圧でも同様に, 48〜 72時間における平均血圧 は死亡群で有意に低かった。

\section{考察}

本研究では, 血圧低下を意味する語句が入室後 24 時間で は生存群に多く, 48〜 72時間後では死亡群で多いという 結果が得られた。

テキストマイニングは膨大な文書情報を定型化し, 分析 を行う手法である5)。分析には文章を単語に分解する処理 (形態素解析) を要するが, 日本文では欧文に比較して単語 が連結しているため容易ではない4)。近年登場したソフト ウェアはこの作業を自動化できるうえ，品詞を判定するこ とができる。このソフトウェアは幅広い分野で使用される ものであるため, 事前処理として医学辞書6)を語句として 登録することで, 効率化を図った。

集中治療分野におけるテキストマイニングでは, 恣意的 な記述が多数含まれる定性デー夕を分析するが,「血圧低 下をカルテに記載し, 報告するかどうかの判断」など, 経 験や能力といった定量データにはない要素が含まれるた め, より早い段階での予測によって治療介入ができる可能 性がある。

本研究においては, 入室 $48 \sim 72$ 時間後では血圧低下の 記載が死亡群で有意に多く, 実際の平均血圧も低值であっ たため, 治療に反応しにくい状況をテキストマイニングの デー夕も示唆している可能性がある。一方, 入室 24 時間以 内では実際の血圧で有意な差がないにもかかわらず, 血圧 低下の記載が生存群で多かった。積極的な異常高血圧への 対応や「血圧低下」への対応が病態の遷延を防いだ可能性が あるが, 解釈が困難であり, 今後の検討課題の一つである。

テキストマイニングの問題点としては, テキストデータ の抽出がシステムによっては困難なこと, 専門用語や略語 が自動的に解析できないこと, 施設ごとのカルテ記載の
ルールが異なること, などが挙げられる。さらに, カルテ 記載を行うかどうかやその内容は, 看護師の経験や実力に 大きく左右される点は, 今後の検討課題である。

また，一般的にテキストマイニングは，多岐にわたる要 素から注目すべき因子に焦点を当てることが目的であり， 定量データでの統計学的解析による検証が不可欠であるこ とには注意が必要である。今回は実際の平均血圧を収集し た。

今回の手法は上述のように課題が多いが, 様々な疾患や パラメータにも容易に転用可能であり, 今後血圧以外のパ ラメータや, 敗血症以外の疾患などでも解析して, テキス トマイニングの有用性をさらに検討していきたい。

\section{結 語}

敗血症患者の看護記録におけるテキストマイニング解析 において,「血圧低下」の記録は入室後 24 時間では生存群 に多く, 48〜 72時間後では死亡群で有意に多かった。

本稿の全ての著者には規定されたCOIはない。

\section{文 献}

1) Henry KE, Hager DN, Pronovost PJ, et al. A targeted real-time early warning score (TREWScore) for septic shock. Sci Transl Med 2015;7:299ra122.

2) Singer M, Deutschman CS, Seymour CW, et al. The third international consensus definitions for sepsis and septic shock (Sepsis-3). JAMA 2016;315:801-10.

3) Doctor Robertの IME用無料医学辞書. [cited 2016 June 16]. Available from: http://ladygodiva.web.fc2.com/igaku/igaku_ jisyo.html

4) 鈴木 肇. 形態素解析とキーワード抽出及び, 自動要約の可 能性. 産業経济研究所紀要 2008;18:107-12.

5) 齋藤朗宏. 日本におけるテキストマイニングの応用. The society for economic studies, The University of Kitakyushu, Working Paper Series 2012;2011-12. Available from: http:// www.kitakyu-u.ac.jp/economy/study/pdf/2011/2011_11.pdf

6) 石原健太, 山本幸也, Weissenbacher D, 他. 電子カルテから の医療用語抽出. 言語処理学会第 17 回年次大会発表論文集 2011;244-7. 